\title{
MORPHOLOGICAL AND PHYSIOLOGICAL RESPONSES OF PURPLE CHRYSANTHEMUM (ASTER SPHATHULIFOLIUS) UNDER LONG-TERM STRESS OF CALCIUM CHLORIDE AS DEICING SALT
}

\author{
JU, J.-H. ${ }^{1}-$ YEUM, K.-J. ${ }^{2}-$ SON, H.-M. ${ }^{3}-$ YOON, Y.-H. ${ }^{1 *}$ \\ ${ }^{1}$ Department of Green Technology Convergence, KonKuk University, 268 Chungwondaero, \\ Chungju-si, Chungcheongbuk-do 27478, South Korea \\ ${ }^{2}$ Division of Food Bioscience, KonKuk University, 268 Chungwondaero, Chungju-si, \\ Chungcheongbuk-do 27478, South Korea \\ ${ }^{3}$ Department of Green Technology Convergence, Graduate School of Natural Science, KonKuk \\ University, 268 Chungwondaero, Chungju-si, Chungcheongbuk-do 27478, South Korea \\ *Corresponding author \\ e-mail: yonghan7204@kku.ac.kr; phone: +82-43-840-3538; fax: +82-43-851-4169 \\ (Received $3^{\text {rd }}$ Aug 2017; accepted $5^{\text {th }}$ Dec 2017)
}

\begin{abstract}
Long-term research on the effect of deicers on groundcover plants can open up usage of groundcover plants for ornamental purposes on the roadside affected by deicer salt. The objective of this study was to investigate the long-term effect of $\mathrm{CaCl}_{2}$ on morphological and physical responses of purple chrysanthemum (Aster sphathulifolius) grown in a greenhouse. Five different concentrations $(0,1,2,5$, 10 , and $15 \mathrm{~g} / \mathrm{L})$ of road deicer $\left(\mathrm{CaCl}_{2} 74 \%\right)$ solutions $(100 \mathrm{ml})$ were applied twice a week for a 5 month period. Survival rate, growth parameter, biomass, and physiological indices were measured. Increased $\mathrm{CaCl}_{2}$ concentration resulted in decreased survival rate, especially at concentrations higher than $10 \mathrm{~g} / \mathrm{L}$. Exposure to increasing $\mathrm{CaCl}_{2}$ concentrations resulted in dramatic decreases in growth index, number of leaves, leaf width, and leaf length at concentration higher than $2 \mathrm{~g} / \mathrm{L}$. Biomass was also negatively affected by increasing deicer salt stress, with shoot mass being reduced more than root fresh weight. Chlorophyll $b$ content was decreased, while chlorophyll $a$ and proline contents in leaves had a gradual increase when plants were exposed to increasing salt stress. Although a clear roadside negative effect did exist, there was no significant difference between plants under $1 \mathrm{~g} / \mathrm{L}$ of $\mathrm{CaCl}_{2}$ and control treatment for 5 months. Our results suggest that Aster sphathulifolius planting could be highly beneficial to the roadside or urban areas with mildly salt-affected soils.
\end{abstract}

Keywords: calcium chloride; ornamental groundcovers, road deicer; soil-plant continuum; tolerance of salt stress

\section{Introduction}

Deicing salt has been used for decades to melt snow and ice from the road to improve traffic safety in winter (Viskari and Kärenlampi, 2000). However, these salts are eventually displaced to roadside areas where they can negatively impact soils, vegetation, and water resources (ground or surface) (Devitt et al., 2014). A high amount of deicer has been used in South Korea due to its geographically distinctive winter season characterized by snowfall. On roads, $\mathrm{CaCl}_{2}$ has been used as one of the most popular road deicer in South Korea (Shin et al., 2010), because it is more effective at low temperatures. Thus, at roadside areas that use $\mathrm{CaCl}_{2}$, the $\mathrm{Cl}^{-}$concentration is higher than the other sites. The use of deicing salts on roads has resulted in high concentrations of chloride $(577 \sim 2,353 \mathrm{mg} / \mathrm{kg}$ ) in urban roadside soil (Zhang et al., 2012). This is probably due to heavy volume of traffic at these sites (Baek et al., 2014). With 
increasing of salts content, a large amount of ions enter the cells, thereby morphology and physiology of plants growing under salt stress are adversely affected (Cao et al., 2012). Even though $\mathrm{CaCl}_{2}$ has on plant physiology include membrane permeability and reduction in $\mathrm{Na}^{+}$concentration within a certain limit (Amuthavalli et al., 2012). Therefore, ways to reduce salt damage should be presented including a planting guide to match species to a site. The harmful effects of deicing salt on roadside herbs and grasses depends on the sensitivity of plant species (Ali et al., 2012). Planting salt tolerant ornamental groundcover plants can be a very effective strategy to utilize deicer salt affected soils. Salt tolerance varies widely among plant species and genotype. Plants can adapt to salinity by tolerating or avoiding salt uptake. Some plants can achieve salt tolerance by osmotic adjustment (Mao et al., 2008). Many researchers have studied salt tolerance of herbaceous plants after they are exposed to high salts. Eom et al. (2007) have shown that salt tolerance of six groundcover species is different in response to $\mathrm{NaCl}$ treatment $(0 \sim 400 \mathrm{mM})$. It can be grouped into three categories: highly sensitive to salt treatment (Sedum acre), intermediately sensitive (Achemilla mollis, Nepeta $\times$ faassenii, Thymus praecox, and Phlox subulata), and tolerant (Solidago cutleri). Ali et al. (2012) have reported that the ornamental plant Anternanthera bettzickiana can be characterized as a salt-tolerant glycophyte. Other studies have also reported salt tolerance of other ornamental herbaceous plants, including Suaeda salsa (Guan et al., 2011), Foeniculum vulagre (Semiz et al., 2012), Eugenia myrtifolia (Acosta-Motos et al., 2015), Aster perennials (Wu et al., 2016), Salvia splendens and Ageratum houstonianum (Jędrzejuk et al., 2016), and Sedum species, Allium species, and a mixture of turf grasses (Whittinghill and Rowe, 2011). Salt tolerance has also been demonstrated for woody plants such as Ardisia japonica (Lee et al., 2008), ornamental shrubs (Cassaniti et al., 2009), Prosopis glandulosa (Moore et al., 2010), Atriplex nummularia (Alharby et al., 2014), and Rosa rubigionsa (Hura et al., 2017). However, to the best of our knowledge, no study has reported the salt tolerance of Aster spathulifolius for a long-term. Also, the effect of calcium chloride deicer on ornamental herbaceous plants compared to $\mathrm{NaCl}$ remains to be investigated.

Asteraceae is one of the largest plant families with many important ornamental species (Wu et al., 2016). Seashore spatulate aster, specifically, Aster spathulifolius Maxim, is halophyte, which typically found on the coast areas of Korea. Because the demend for road deicers continues to increase, long-term research on the effect of deicers on groundcover plants is needed. Therefore, the objective of this study was to determine the effect of $\mathrm{CaCl}_{2}$ on morphological and physiological responses of Aster spathulifolius.

\section{Material and methods}

\section{Plant material and growth conditions}

Seedlings of Aster sphathulifolius were purchased from a commercial nursery (Sannea Botanical Garden, Chenonan, Chungnam, Korea). All plants with similar sizes used in experiments were 5-6 cm in height with 10-15 fully grown leaves. These seedlings were transferred to $12 \mathrm{~cm}$-diameter pots filled with $0.5 \mathrm{~kg}$ of artificial substrates (Wonjo-mix, NongKyung Inc., Korea) in March 2016. Pots were kept in the laboratory and watered every 2 days in the four weeks following transplanting. The experiment was conducted from April 2016 to October 2016 at KonKuk University, Chungju (latitude, $35^{\circ} 49^{\prime} \mathrm{N}$; longitude, $127^{\circ} 08^{\prime} \mathrm{E}$ ). Plants were grown in the greenhouse under 
natural light. During the study period, air temperature and relative humidity were monitored with a thermo recorder (SK-1260, SATO, Japan). Photosynthetically active radiation (PAR) was measured with a digital light meter (Extech 401025, EXTECH, USA). Average air temperature, relative humidity, PAR were kept at $26.2^{\circ} \mathrm{C}, 62.7 \%$, and $1,500 \mu \mathrm{mol} \cdot \mathrm{m}^{2} / \mathrm{s}$, respectively.

\section{Treatments}

The substrate used for this study was a commercially produced ridging (Nongkyung Floricultural materials, Co., Chungbuk, Korea) with $\mathrm{pH}$ 6.5. Prior to transplanting, each metal was thoroughly mixed with $0.5 \mathrm{~kg}$ of air-dried substrate. The mixture was then used to fill the pots. To evaluate the effect of $\mathrm{CaCl}_{2}$ concentrations on Aster spathulifolius, a completely randomized block design with five treatments was adopted (3 replications, 3 seedlings per replication, total of 45 seedlings). Based on the results of earlier studies (Zhang et al., 2012; Thouvenot et al., 2012) on roadside soil concentration of chloride ions, $\mathrm{CaCl}_{2}$ powder ( $74 \%$ of calcium chloride, Oriental Chemical Industries, Korea) was diluted in distilled water to obtain concentrations at 0 (Control), 1 (C1), 2 (C2), 5 (C5), 10 (C10), and $15 \mathrm{~g} / \mathrm{L}$ (C15) corresponding to 0.5, 7, $14,35,70$, and $105 \mathrm{mM}$, respectively. Aster sphathulifolius seedlings were watered with $100 \mathrm{ml}$ of $\mathrm{CaCl}_{2}$ solution twice a week until the end of the experiment (for 5 months).

\section{Measurements}

The number of plants that were survived was recorded. This number was then used to estimate the survival rate (percentage). Plants that maintained 3 to 6 green or greenish and elongating leaves were scored as being alive (survived). Those with all leaves dried out were scored as dead. Survival rates were calculated with the following formula (Kanawapee et al., 2012): Survival rate $=($ survived plants/ total plants $) \times 100(\%)$.

The following growth parameters were observed: growth index, leaf number, leaf length, and leaf width. Growth index was measured once a month for each group of seedlings in May and September 2016 during peak growth period. Plant height $(\mathrm{H})$ at the tallest point and width at the widest point in two directions (left to right and front to back: W1, W2) were also measured (Whittinghill and Rowe, 2011). Data of height and width were used to calculate growth index $[(\mathrm{W} 1+\mathrm{W} 2) / 2+\mathrm{H}] / 2$ which is commonly used as an indicator of plant size (Hammond et al., 2007). Length of leaf, width of leaf, and leaf number on the stem were also measured for Aster sphathulifolius. These growth parameters were partially based on the relative growth rates (RGR) of plants (Thouvenot et al., 2012): RGR = (In L2- In L1)/(T2-T1), where L1 and L2 were total length at time 1 and time 2, respectively.

Each plant harvested was then divided into shoots (leaves and stem) and roots after 5 months of treatments. Fresh weights $(\mathrm{FW})$ were measured after different organs were washed with distilled water. Shoots and roots were then dried in a drying oven (C-DF, Changshin Scientific Co., Korea) at $70{ }^{\circ} \mathrm{C}$ until they reached a constant weight in order to measure their respective dry weights (DW). To evaluate salinity tolerance, relative dry weight (RDW) was calculated as a ratio of average values for each accession of seedlings (Chen et al., 2013): DW (salt treatment)/DW (control) $\times 100(\%)$, a trait commonly used to measure salinity tolerance.

Chlorophyll was extracted following the method outlined by Baruah et al. (2014). Briefly, collected leaves of experimental plants were washed properly and $100 \mathrm{mg}$ of 
fresh leaves from those plants was weighed and cut into small pieces with a razor. Chlorophyll pigment was then extracted by grinding these cut leaves with a mortar and pestle for $5 \mathrm{~min}$ in about $8 \mathrm{ml}$ of $95 \%(\mathrm{v} / \mathrm{v})$ acetone. The extract was filtered with Whatman number 1 filter paper. The filtrate was transferred to a $100-\mathrm{ml}$ volumetric flask. The volume of the filtrate was increased to $10 \mathrm{ml}$ by addition of $95 \%$ acetone. After that, optical density (OD) of the extract was measured using a spectrophotometer (Biochrom Libra S22, Biochrom, England) at wavelength of $645 \mathrm{~nm}$ and $663 \mathrm{~nm}$ using 95\% acetone as a blank. The wavelengths chosen the maximum absorption wavelengths for total chlorophyll and chlorophyll $\mathrm{a} / \mathrm{b}$, respectively. The amount of chlorophyll a and $\mathrm{b}$ and total chlorophyll content of leaf tissues (in $\mathrm{mg} / \mathrm{g}$ ) were calculated using the following equations:

$$
\begin{gathered}
\text { Chlorophyll } \mathrm{a}=[12.7(\mathrm{OD} 663 \mathrm{~nm})-2.69(\mathrm{OD} 645 \mathrm{~nm})] \times(\mathrm{V} / 1000 \mathrm{~W}) \\
\text { Chlorophyll } \mathrm{b}=[22.9(\mathrm{OD} 645 \mathrm{~nm})-4.68(\mathrm{OD} 663 \mathrm{~nm})] \times(\mathrm{V} / 1000 \mathrm{~W}) \\
\text { Total chlorophyll }=[20.2(\mathrm{OD} 645 \mathrm{~nm})+8.02(\mathrm{OD} 663 \mathrm{~nm})] \times(\mathrm{V} / 1000 \mathrm{~W})
\end{gathered}
$$

Proline content was analyzed with the modified procedure of Kanawapee et al. (2012). Briefly, the third and fourth leaves from the apical shoot of three plants per treatment were frozen immediately in liquid nitrogen at harvest. Approximately $0.1 \mathrm{~g}$ of leaf was homogenized with $5 \mathrm{ml}$ of $3 \%$ aqueous sulfosalicylic acid. Two $\mathrm{ml}$ of the extract was then reacted with $2 \mathrm{ml}$ of acid ninhydrin and $2 \mathrm{ml}$ of glacial acetic acid followed by boiling in a water bath at $100^{\circ} \mathrm{C}$ for $1 \mathrm{~h}$. The reaction was stopped by placing the tubes on ice. The solution was then extracted with $4 \mathrm{ml}$ of toluene and the absorbance of the toluene fraction was measured by spectrophotometry (Biochrom Libra S22, Biochrom, England) at wavelength of $520 \mathrm{~nm}$. The amount of free proline was evaluated using a standard curve and expressed as $\mu \mathrm{g} / \mathrm{g}$ tissue fresh weight.

\section{Statistical analysis}

Data are presented as mean \pm standard deviation of nine replicates $(N=9)$. Statistical analysis was performed using SPSS 18.0 for Windows (SPSS Inc., Chicago, IL, USA) by one-way analysis of variance (ANOVA). Treatment means were separated with Duncan's Multiple Range Test $(P \leq 0.05)$.

\section{Results}

The survival rate of Aster sphathulifolius showed no significant difference between treatments in the initial stage. However, at the end of 5 months under salt stress conditions, survival rates of plants were reduced sharply in the following order: $\mathrm{CaCl}_{2} 0$ $($ Control; $100 \%)>\mathrm{CaCl}_{2} 1(\mathrm{C} 1 ; 100 \%)>\mathrm{CaCl}_{2} 2(\mathrm{C} 2 ; 80 \%)>\mathrm{CaCl}_{2} 5(\mathrm{C} 5 ; 70 \%)>$ $\mathrm{CaCl}_{2} 10(\mathrm{C} 10 ; 0 \%)>\mathrm{CaCl}_{2} 15 \mathrm{~g} / \mathrm{L}(\mathrm{C} 15 ; 0 \%)$. The survival rate of Aster sphathulifolius were significantly decreased compared to those of control as well as 1 $\mathrm{g} / \mathrm{L}$ of $\mathrm{CaCl}_{2}$ treated plants. Increasing $\mathrm{CaCl}_{2}$ concentration in the substrates resulted in decreasing survival rate, especially when its concentration was higher than $10 \mathrm{~g} / \mathrm{L}$ (Figure 1). 


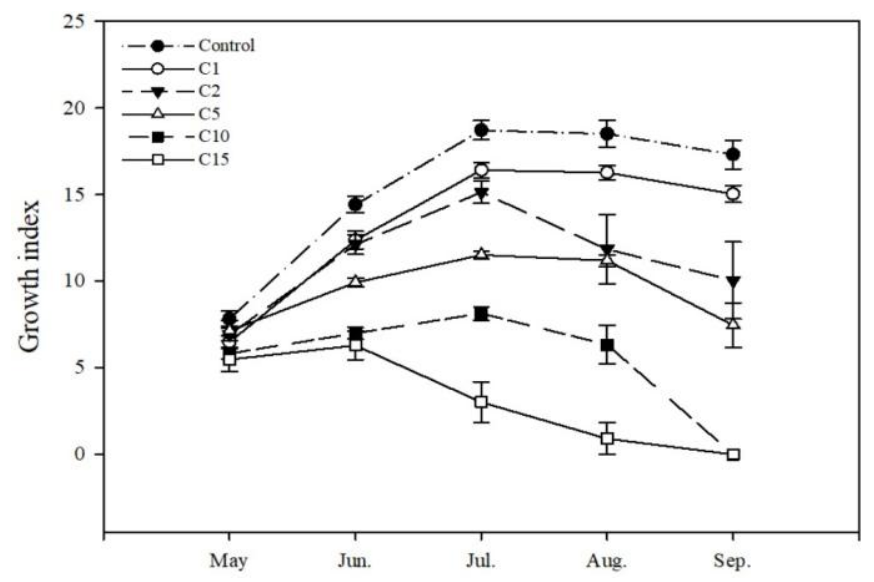

Figure 1. Survival rates of Aster sphathulifolius after treated with $\mathrm{CaCl}_{2}$ at different concentrations $(0,1,2,5,10$, and $15 \mathrm{~g} / \mathrm{L}$ as Control, C1, C2, C5, C10, and C15, respectively) for 5 months. Values are presented as means $\pm S E$ of nine replications.

The growth index of Aster sphathulifolius showed various degrees of growth retardation, although some differences existed between treatments with different $\mathrm{CaCl}_{2}$ concentrations in June. However, the average growth indices of Control, C1, C2, C5, $\mathrm{C} 10$, and $\mathrm{C} 15$ were significantly decreased $(P \leq 0.05)$ by $17.3,15.2,15.2,11.8,8.2,6.7$ $\mathrm{cm}$, respectively in July, and plants grown in C10 and C15 treatment groups did not survive in September. The average growth indices of C1, C2, and C5 treatment groups were 20, 22, and 47\%, respectively, compared to the control. For all treatements, the number of leaves showed a increase resulting in a range from 14.4 (C15) to $66.5 \%$ (Control) deicing salt stress in June, but then gradually decreased by 3.1 (Control) and $82.6 \%(\mathrm{C} 15)$ in response to salinity stress. The number of leaves of plants in $\mathrm{C} 1, \mathrm{C} 2$, and C5 treatment groups was significantly lower $(P \leq 0.05)$ by 9,18 , and $57 \%$, respectively, compared to that in the control at 5 months after treatment. However, there was no significant difference in the number of leaves between the Control and $\mathrm{C} 1$ treatment. Exposure to increasing $\mathrm{CaCl}_{2}$ concentrations resulted in dramatic decreases in leaf width and leaf length with $\mathrm{CaCl}_{2}$ at $1,2,5$, and $10 \mathrm{~g} \cdot \mathrm{L}^{-1}$, leaf widths were 32,33 , 22, and $19 \mathrm{~mm}$, respectively, while leaf lengths were 89, 92, 84, and $62 \mathrm{~mm}$, respectively. There was no significant difference in leaf width or length between plants under Control and those with $\mathrm{C} 1$ treatment (Figure 2).

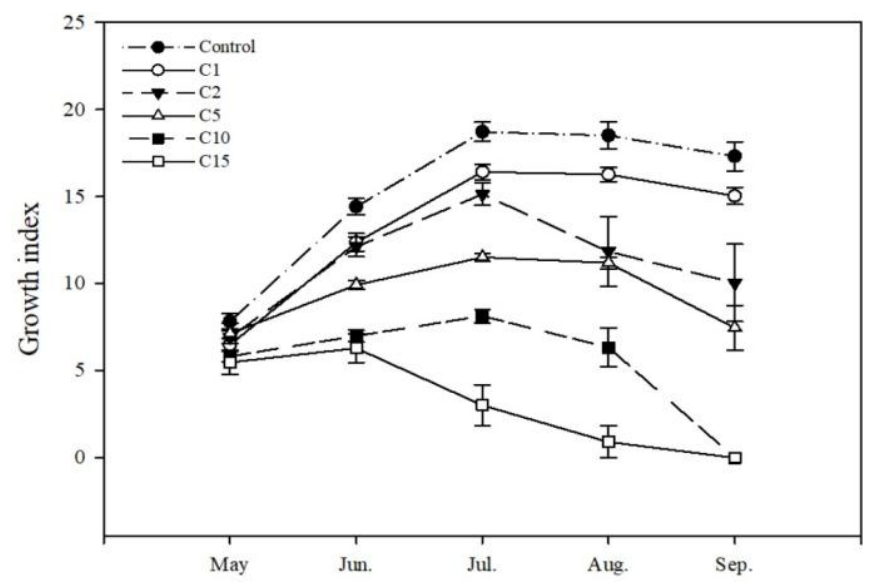

(A) : Growth index 


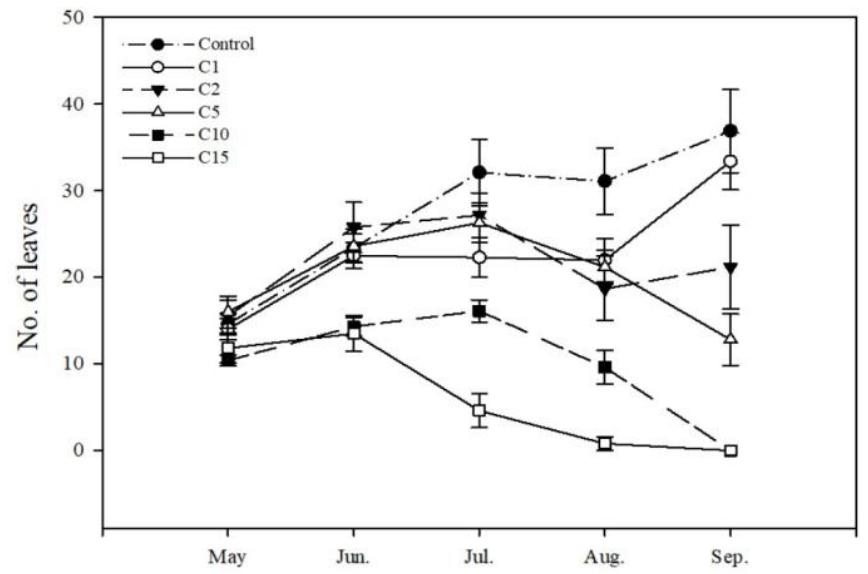

(B): Number of leaves

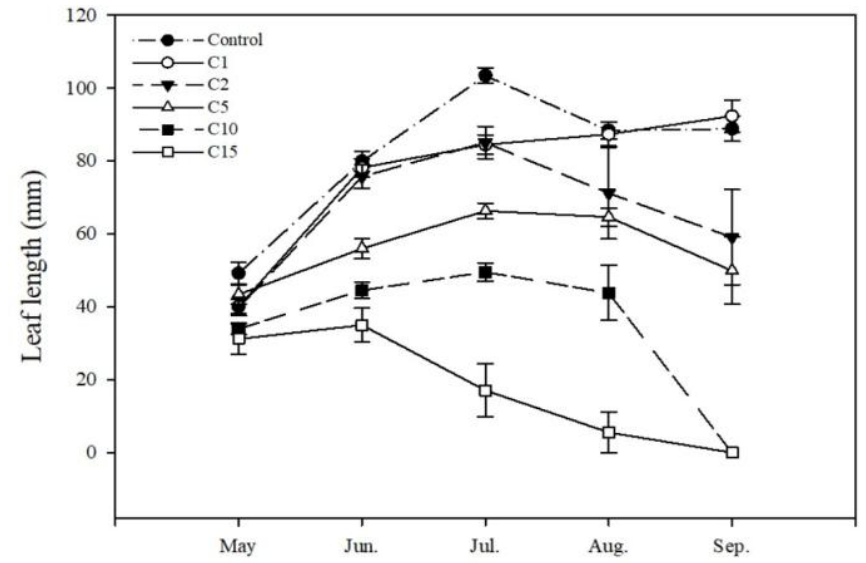

(C) : Leaf length

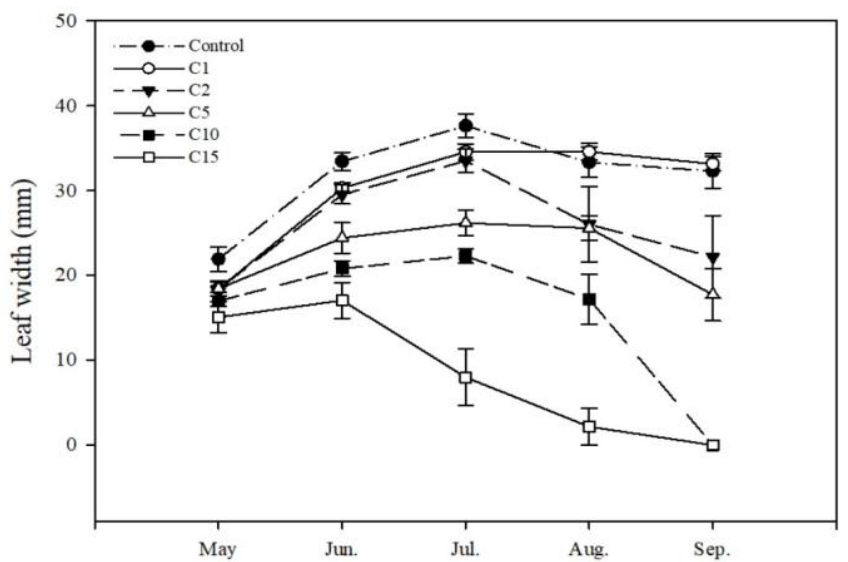

(D) : Leaf width

Figure 2. Growth index(A), number of leaves(B), leaf width(C), and leaf length $(D)$ of Aster sphathulifolius grown under $\mathrm{CaCl}_{2}$ stress at various concentrations $(0,1,2,5,10$, and $15 \mathrm{~g} / \mathrm{L}$ as Control, C1, C2, C5, C10, and C15, respectively) for 5 months. Values are presented as means $\pm S E$ of nine replications.

As shown in Figure 3, exposure to increasing concentrations of calcium chloride resulted in dramatic decrease $(P \leq 0.05)$ in biomass of Aster sphathulifolius compared to non-salt stress. Shoot showed more reduction than root fresh weight of Aster 
sphathulifolius. Average shoot fresh weights of plants in C1, C2, C5, C10, and C15 treatment groups were reduced by $3,36,56,89$, and $92 \%$, respectively, while root fresh weights were reduced by $41,50,66,83$, and $88 \%$, respectively in comparison with those in the Control $\left(\mathrm{CaCl}_{2} 0 \mathrm{~g} / \mathrm{L}\right)$. Shoot dry weights of salt stressed plants in $\mathrm{C} 1, \mathrm{C} 2, \mathrm{C} 5$, $\mathrm{C} 10$, and $\mathrm{C} 15$ treatment groups were also reduced by $24,31,52,75$, and $81 \%$, respectively, while dry weights were reduced by 39, 46, 59, 67 and $74 \%$, respectively, compared to those of Control (Figure 4). Relative dry weight (RDW), a trait commonly used to measure salinity tolerance, was also substantially reduced by $76.4,69.5,48.5$, $25.4,19.4 \%$ relative to Control (data not referred).

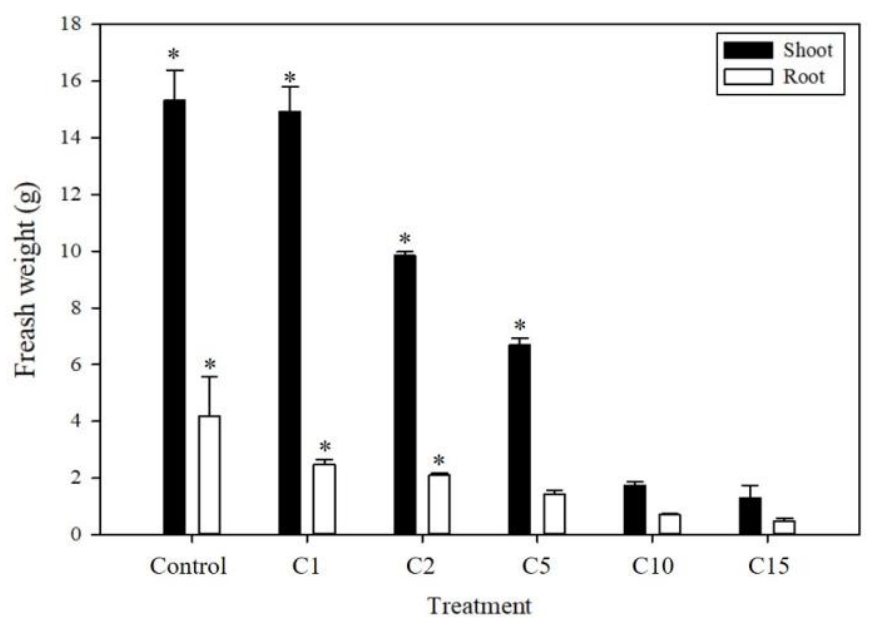

(A) : Fresh weight

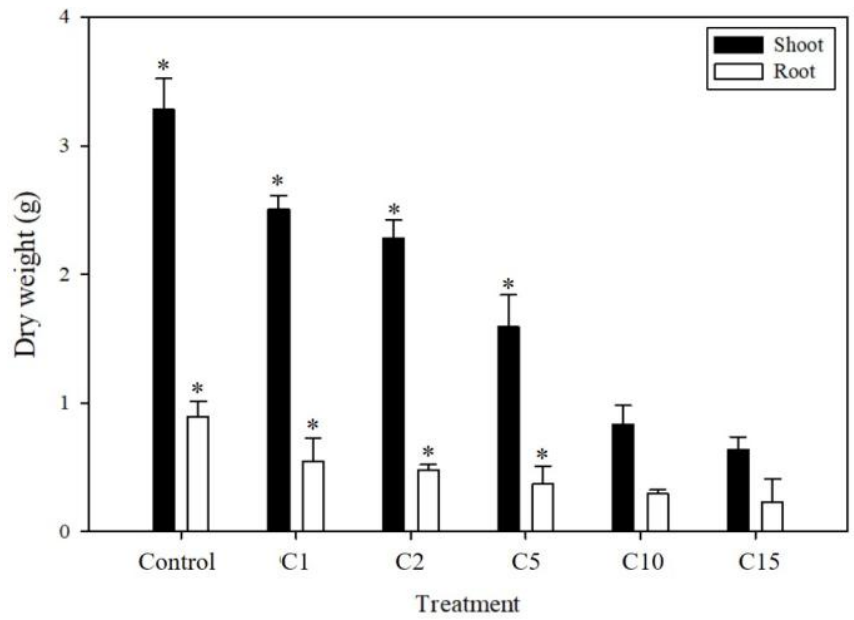

(B): Dry weight

Figure 3 Fresh $(A)$ and dry weight(B) of Aster sphathulifolius grown under $\mathrm{CaCl}_{2}$ stress with at various concentrations $(0,1,2,5,10$, and $15 \mathrm{~g} / \mathrm{L}$ as Control, C1, C2, C5, C10, and C15, respectively) measured after hravest. Values are presented as means $\pm S E$ of nine replications $(* P$ value $\leq 0.05)$.

Salt stress for 5 months affected chlorophyll contents of Aster sphathulifolius. Interestingly, salt stress resulted in significant increase of chlorophyll $a$ content, whereas decrease of chlorophyll $b$ content. The mean chlorophyll $a$ content was increased from 8.2 to $14.97 \mathrm{mg} / \mathrm{g} \mathrm{FW}$. For chlorophyll $b$, the mean was decreased from 21.18 to $11.17 \mathrm{mg} / \mathrm{g}$ FW respectively. Total chlorophyll contents in $\mathrm{C} 1, \mathrm{C} 2, \mathrm{C} 5$, and 
C10 treatments were decreased significantly by 98.6, 95.3, 92.9, and 89.5\%, respectively, compared to those of Control. When Aster sphathulifolius plants were exposed to salt stress, the mean proline contents in the leaves were increased significantly from 23.0 in the control to $37.3 \mu \mathrm{g} / \mathrm{g} \mathrm{FW}$ in C10 treatment (an increase of $62.2 \%$ ). Salinity stress caused a significant increase in proline contents in C2, C5, and $\mathrm{C} 10$ treatment groups when compared with the control and $\mathrm{C} 1$ treatment group (Table 1).

Table 1. Differences of chlorophyll and proline contents of Aster sphathulifolius leaves grown under $\mathrm{CaCl}_{2}$ stress at various concentrations $(0,1,2,5,10$, and $15 \mathrm{~g} / \mathrm{L}$ as Control, C1, C2, C5, C10, and C15, respectively) measured after harvest.

\begin{tabular}{ccccc}
\hline Treatments & $\begin{array}{c}\text { Chlorophyll contents } \\
\mathbf{a} \\
(\mathbf{m g} / \mathbf{g} \text { FW })\end{array}$ & $\begin{array}{c}\text { Chlorophyll } \\
\text { contents } \\
\mathbf{b} \\
(\mathbf{m g} / \mathbf{g} \text { FW })\end{array}$ & $\begin{array}{c}\text { Total } \\
\text { chlorophyll } \\
\text { contents } \\
(\mathbf{m g} / \mathbf{g} \text { FW })\end{array}$ & $\begin{array}{c}\text { Proline } \\
\text { contents } \\
(\boldsymbol{\mu g} / \mathbf{g ~ F W})\end{array}$ \\
\hline Control & $8.29 \mathrm{~d}^{\mathrm{z}}$ & $21.18 \mathrm{a}$ & $29.46 \mathrm{a}$ & $23.00 \mathrm{c}$ \\
$\mathrm{C} 1$ & $12.92 \mathrm{~b}$ & $16.18 \mathrm{~b}$ & $29.09 \mathrm{ab}$ & $23.33 \mathrm{c}$ \\
$\mathrm{C} 2$ & $12.64 \mathrm{c}$ & $15.49 \mathrm{~b}$ & $28.12 \mathrm{abc}$ & $26.00 \mathrm{bc}$ \\
$\mathrm{C} 5$ & $12.88 \mathrm{~b}$ & $14.56 \mathrm{~b}$ & $27.43 \mathrm{bc}$ & $29.67 \mathrm{~b}$ \\
$\mathrm{C} 10$ & $14.96 \mathrm{a}$ & $11.47 \mathrm{c}$ & $26.44 \mathrm{c}$ & $37.33 \mathrm{a}$ \\
$\mathrm{C} 15$ & - & - & - & - \\
\hline
\end{tabular}

${ }^{\mathrm{z}}$ Different letters in the same column indicate significant difference according to Duncan's multiple range test at $P$ $\leq 0.05(\mathrm{n}=9)$.

\section{Discussion}

Plant survival and productivity is crucial for seedling establishment under saline conditions (Ponte et al., 2014). In this study, no significant correlation between plant suvival and $\mathrm{CaCl}_{2}$ concentrations were found initially, however, after treatment for 5 months, a significant negative correlation was observed between the survival rate and the dose of $\mathrm{CaCl}_{2}$. Higher $\mathrm{CaCl}_{2}$ concentrations were associated with lower survival rate for a long term exposure, although Aster sphathulifolius is a halophyte that has grown and evolved under saline conditions. Soil salinity can inhibit plant growth by a number of mechanisms including low external water potential, toxicity of absorbed $\mathrm{Cl}^{-}$ions, inhibition of various enzymatic activities and different cellular processes, and interference with the uptake of essential nutrients (Taffoue et al., 2014). The fundamental mechanisms of salt tolerance in salt tolerant plants seem to be mostly dependent on their capacities to sequestrate toxic ions in vacuoles and accumulate compatible osmotic pressure in the cytoplasm as previously suggested (Munns, 2002). Salt tolerance of herbaceous perennial species including Achemilla mollis, Nepeta $\times$ faassenii, Sedum acre, Tymus praecox, Phlox subulata, and Solidago cutleri, to aqueous solution of sodium chloride at $0 \sim 400 \mathrm{mM}$ over a 21 day period has been evaluated by measuring their growth. These plants were grouped into three tolerance categories : highly sensitive to salt treatment (Sedum acre), those with intermediate sensitivity $(A$. mollis, N. $\times$ faassenii, $T$. praecox, and $P$. subulata $)$, and those with salt tolerance $(S$. 
cutleri) (Eom et al., 2007). It has been reported that Alternanthera bettzickiana can grow even at a salinity level of $40 \mathrm{dS} / \mathrm{m}$ (Ali et al., 2012). In addition, it has been found that the critical level of species sensitive to chloride ions is $4 \sim 7 \mathrm{mg} / \mathrm{g}$ and that of species tolerant to chloride ions is $15 \mathrm{mg} / \mathrm{g}$ (Xu et al., 2000; White and Broadley, 2001). Considering this, it is generally accepted that Aster sphathulifolius could be able to grow at salt levels less than $1 \mathrm{~g} / \mathrm{L}\left(\mathrm{Cl}^{-}\right.$agent $\left.0.094 \mathrm{~g} / \mathrm{L} \mathrm{day}{ }^{-1}\right)$ for 5 months.

Biomass of seedlings is a trait commonly used to measure salinity tolerance (Chen et al., 2013). Eupatorium greggii, Viguiera stenoloba, and Santolina chamaecyparissus were the most salt-tolerance species with less redutions in shoot dry weight (Wu et al., 2016). It has been reported that Alternanthera bettzickiana plants at salinitiy level of 20 $\mathrm{dS} / \mathrm{m}$ will produce $30.3 \%$ less biomass than controls. Further increasing salinity will lead to lower biomass in response to higher salt stress (Ali et al., 2012). Similarly, Semiz et al. (2012) have also reported that the biomass of Foeniculum vulgare is also affected negatively by chloride ions. Meanwhile, chloride ions $\left(\mathrm{Cl}^{-}\right)$in soil is recognized as one key contributor to the decrease in the production of plants. The critical concentration of chloride ions is found to be $0.49 \mathrm{~g} / \mathrm{L}$. At this concentration, the biomass of plants is decreased by 10\% (Dang et al., 2008). Considering the actual concentrations of chloride ions $\left(\mathrm{Cl}^{-}\right)$in $\mathrm{C} 1, \mathrm{C} 2, \mathrm{C} 5, \mathrm{C} 10$, and $\mathrm{C} 15$ treatments are 0.047 , 0.094, 0.236, 0.472, and $0.708 \mathrm{~g} / \mathrm{L} \mathrm{day}^{-1}$, respectively, Aster sphathulifolius should be able to grow in roadside or urban soils contaminated by deicing salt because relatively low $\mathrm{Cl}^{-}$concentrations are present in these field conditions.

The chlorophyll meter is a simple tool used to measure relative chlorophyll content or greenness. It is an efficient indicator of stress in plants (Netto et al., 2005). Changes in chlorophyll content of plants under salt stress dependeds on stress rate and plant species (Eom et al., 2007; Younes et al., 2016). Nadeem et al. (2006) have reported that salt stress can decrease chlorophyll pigments ( $\mathrm{a}, \mathrm{b}$, and carotenoids contents) of plant. However, another study has shown that chlorophyll content cannot be used as an indicator of salt tolerance ability (Kanawapee et al., 2012). Although plant species can differ considerably in total amount of chlorophyll content under salt stress, results from this study suggest that chlorophyll content might be considered as an additional trait useful for screening salt tolerance.

Relative abundance of compatible solutes including proline is an important protective factor for plants under salt stress (Norastehnia et al., 2014; Abbas et al., 2014). Salinity stress has caused a significant increase in proline concentration in shoots of plants compared to that in the control (non-stressed seedlings) (Kamawapee et al., 2012). In response to salt stress, proline accumulation in plants has been implicated to play adaptive roles in osmoregulation and salt stress signaling (Szabados and Savouré, 2009; García-Caparrós et al., 2016). Our results revealed that proline content in plants under salt stress were apparently higher than those in plants under non- salt stress condition. Plants showed significantly higher levels of proline content compared to plants without $\mathrm{CaCl}_{2}$ stress. These results suggest that proline accumulation might be considered as an additional trait useful for screening plants for salt tolerance ability.

Results of this study showed that increasing $\mathrm{CaCl}_{2}$ concentrations dramatically reduced survival rate and plant growth of Aster sphathulifolius. Biomass was also affected negatively by increasing salt stress of $\mathrm{CaCl}_{2}$, with shoots having more reduction in mass than root fresh weight. Calcium chloride salt stress significantly increased chlorophyll $a$ and proline contents in leaves, but decreased chlorophyll $b$. 


\section{Conclusion}

Salt tolerant ornamental groundcover plants can be a very effective strategy to utilizing deicer salt affected soils. The morphological and pysiological responses of Aster sphathulifolius indicated that the one gram dosage of $\mathrm{CaCl}_{2}$ for 5 months had no significant difference in survival rates and growth parameters as compared to those of control. However there was a significant negative effect exist by the cumulative dose of deicing $\mathrm{CaCl}_{2}$ salt( $\left.>1 \mathrm{~g} / \mathrm{L}\right)$. These results suggest that planting Aster sphathulifolius could be highly beneficial for sites with salinity soils such as roadside or urban areas since relatively low $\mathrm{Cl}^{-}$concentrations are present in these fields. In the future, soilchloride-plant continuum study warrants to determine the effect of deicers on diverse ecological characteristics of roadside groundcover plants.

Acknowledgements. This research was supported by Basic Science Research Program through the National Research Foundation of Korea (NRF) funded by the Ministry of Science, ICT \& Future Planning (2015RIC1A2A01052633).

\section{REFERENCE}

[1] Abbas, M.F., Jasim, A.M., Al-Taha, H.A. (2014): Effect of proline and salt stress on organogenesis, growth, proline and carbohydrate content of regenerated plantlets in Citrus sinensis (L.) Osbeck cv. local orange. - Advances in Agriculture and Botanics International Journal of the Bioflux Socity 6(2):186-198.

[2] Acosta-Motos, J.R., Diaz-Vivancos, P., Alvarez, S., Fernandez-Garcia, N., SanchezBlanco, M.J., Hernandez, J.A. (2015): Physiological and biochemical mechanisms of the ornamental Eugenia myrtifolia L. plants for coping with NaCl stress. - Planta 242(4):829846.

[3] Alharby, H.F., Colmer, T.D., Barrett-Lennard, E.G. (2014): Salt accumulation and depletion in the root-zone of the halophyte Atriplex nummularia Lindl.: influence of salinity, leaf area and plant water use. - Plant Soil 382: 31-41.

[4] Ali, A., Iqbal, N., Ali, F., Afzal, B. (2012): Alternantera bettzickiana (Regel) G. Nicholson, a potential halophytic ornamental plant: Growth and physiological adaptations. - Flora 207(4): 318-321.

[5] Amuthavalli, P., Anbu, D., Sivasankaramoorthy, S. (2012): Effect of calcium chloride on growth and biochemical constituents of cotton (Gossypium hirsutum L.) under salt stress. - Int. J. Res. Bot. 2:9-12.

[6] Baek, M.J., Yoon, T.J., Kim, D.G., Lee, C.Y., Cho, K.J., Bae, Y.J. (2014): Effects of road deicer runoff on benthic macroinvertebrate communities in Korean freshwaters with toxicity tests of calcium chloride $\left(\mathrm{CaCl}_{2}\right)$. - Water Air Soil Pollut. 225: 1961-1966.

[7] Baruah, P., Saikia, R.R., Baruah, P.P., Deka, S. (2014): Effects of crude oil contamination on the chlorophyll content and morpho-anatomy of Cyperus brevifolius (Rottb.) Hassk. Environ. Sci. Pollut. Res. 21: 12530-12538.

[8] Cao, Z., Zhou, X., Bai, C. (2012): Protection and treatment of landscape plant secondary disasters (deicing agent damage) caused by extreme weather. - Journal of Landscape Research 4:61-64.

[9] Cassaniti, C., Leonardi, C., Flowers, T. J. (2009): The effect of sodium chloride on ornamental shrubs. - Scientia Horticulturae 122(4): 586-593.

[10] Chen, L., Ren, J., Shi, H., Chen, X., Zhang, M., Pan, Y., Fan, J., Nevo, E., Sun, D., Fu, J., Peng, J. (2013): Physiological and molecular responses to salt stress in wild emmer and cultivated wheat. - Plant Mol. Biol. Rep. 31: 1212-1219. 
[11] Dang, Y.P., Dalal, R.C., Mayer, D.G., McDonald, M., Routely, R., Schwenke, G.D., Buck, S.R., Daniells, I.G., Singh, D.K., Manning, W., Ferguson, N. (2008): High subsoil chloride concentrations reduce soil water extraction and crop yield on Vertisols in northeastern Australia. - Crop Pasture Sci. 59(4): 321-330.

[12] Devitt, D.A., Wright, L., Landau, F., Apodaca, L. (2014): Deicing salts; Assessing distribution, ion accumulation in plants and the response of plants to different loading rates and salt mixtures. - Environment and Natural Resources Research 4(1): 73.

[13] Eom, S.H., Setter, T.L., Di Tomasso, A., Weston, L. A. (2007): Differential growth response to salt stress among selected ornamentals. - Journal of Plant Nutrition. 30: $1109-1126$.

[14] García-Caparrós, P., Llanderal, A., Pestana, M., Correia, P. J., Lao, M. T. (2016): Tolerance mechanisms of three potted ornamental plants grown under moderate salinity. - Scientia Horticulturae 201:84-91.

[15] Guan, B., Yu, N., Chen, X., Xie, W., Lu, Z. (2011): Effects of salt stress and nitrogen application on growth and ion accumulation of Suaeda salsa plants. - In: Remote Sens. Environ. Transport. Engin. 2011 International Conference. 8268-8272.

[16] Hammond, H.E., Norcini, J.G., Wilson, S.B., Schoellhorn, R.K., Miller, D.L. (2007): Growth, flowering, and survival of fire wheel Gaillardia pulchella Foug. based on seed source and growing location. - Native Plants J. 8(1): 25-39.

[17] Hura, T., Szewczyk-Taranek, B., Hura, K., Nowak, K., Pawlowska, B. (2017): Physiological Responses of Rosa rubiginosa to saline environment. - Water, Air, and Soil Pollution 228(2): 81.

[18] Jędrzejuk, A., Łukaszewska, A., Pacholczak, A. (2016): Effects of $\mathrm{CaCl}_{2}$ solutions to alleviate drought stress effects in potted ornamentals Salvia splendens and Ageratum houstonianum. - Acta Agrobotanica 69(3): 1-11.

[19] Kanawapee, N., Sanitchon, J., Lontom, W., Threerakulpisut, P. (2012): Evaluation of salt tolerance at the seedling stage in rice genotypes by growth performance, ion accumulation, proline and chlrophyll content. - Plant Soil 358: 235-249.

[20] Lee, J.J., Han, S.G., Kang, C.H., Cho, H.K., Jeong, J.S., Lee, K.B. (2008): Adaptability of saline-tolerant plants selected indoors at reclaimed land . - Plant Soil 358: 235-249. Proc. 2008 Fall Symposium Korean J. Plant Resour. : 111.

[21] Mao, H.P., Iwanaga, F., Yamanaka, N., Yamamoto, F. (2008): Growth, photosynthesis, and ion distribution in hydroponically cultured Populus alba L. cuttings grown under various salinity concentrations. - Landscape Ecol. Eng. 4: 75-82.

[22] Moore, G.W., Barre, D.A., Owens, M. K. (2010): Changes in soil chloride following shrub removal and subsequent regrowth. - Geoderma 158: 148-155.

[23] Munns, R. (2002): Comparative physiology of salt and water stress. - Plant Cell Environ. 25: $239-250$.

[24] Nadeem, S.M., Zahir, Z.A., Naveed, M., Arshad, M., Shahzad, S.M. (2006): Variation in growth and ion uptake of maize due to inculation with plant growth promoting rhizobacteria under salt stress. - Soil and Environment 25: 78-84.

[25] Netto, A.T., Campostrini, E., Oliveira, J.G., Bressan-Smith, R.E. (2005): Photosynthetic pigments, nitrogen, chlorophyll a fluorescence and SPAD-502 readings in coffee leaves. - Sci. Hortic. 104: 199-209.

[26] Norastehnia, A., Niazazari, M., Sarmad, J., Rassa, M.. (2014): Effects of chloride salinity on non-enzymatic antioxidant activity, proline and malondialdehyde content in three fluecured cultivars of tobacco. - J. Plant Develop. 21: 75-82.

[27] Ponte, L.F.A., Silva, A.L.C., Carvalho, F.E.L., Maia, J.M., Voigt, E.L. Silveira, J.A.G. (2014): Salt-induced delay in cotyledonary globulin mobilization is abolished by induction of proteases and leaf growth sink strength at late seedling establishment in cashew. - Journal of Plant Physiology 171(15): 1362-1371. 
[28] Semiz, G.D., Unlukara, A., Yurtseven, E., Suarez, D.L., Telci, I. (2012): Salinity impact on yield, water use, mineral and essential oil content of fennel (Foeniculum vulgare Mill.). - J. Agri. Sci. 18: 177-186.

[29] Shin, S.P., Yang, C.H., Ha, D.S., Baek, B.K., Cha, J.S. (2010): Study of assumption of functional adequate amount for the additional deicer save. - Korean Society of Road Engineers 12(4): 51-54.

[30] Szabados, L., Savouré, A. (2009): Proline: a multifunctional amino acid. - Trends Plant Sci. 15(2): 89-87.

[31] Taffouo, V.D., Sondi, S.E., Meguekam, L.T., Nouck, A.E., Wamba, O.F., Youmbi, E. (2014): Changes in growth and nutrient uptake in response to foliar application of sodium and calcium chloride in cowpea cultivars (Vinga unguiculata L. Walp). - Afr. J. Biotechnol. 13(47): 4382-4389.

[32] Thouvenot, L., Haury, J., Thiébaut, G. (2012): Responses of two invasive macrophyte species to salt. - Hydrobiologia 686: 213-223.

[33] Viskari, E.L., Kärenlampi, L. (2000): Roadside Scots pine as an indicator of deicing salt use - a comparative study from two consecutive winters. - Water, Air, and Soil Pollution 122: 405-419.

[34] White, P.J., Broadey, M.R. (2001): Chloride in soils and its uptake and movement within the plant: a review. - Ann. Bot. 88(6): 967-988.

[35] Whittinghill, L.J., Row, D.B. (2011): Salt tolerance of common green roof and green wall plants. - Urban Ecosyst. 14: 783-794.

[36] Wu, S., Sun, Y., Niu, G., James, A., Raul, C. (2016): Response of 10 Aster species to saline water irrigation. - HortScience 51(2): 197-201.

[37] Xu, G., Magen, H., Tarchitzky, J., Kafkafi, U. (2000): Advances in chloride nutrition of plants. - Adv. Agron. 68: 97-150.

[38] Younes, K.A., Raouf, S.S., Mohammad, S., Morteza, B. (2016): Effect of zinc and bio fertilizers on antioxidant enzymes activity, chlorophyll content, soluble sugars and proline in Triticale under salinity condition.

[39] Zhang, Y., Li, F., Sun, T., Wang, J. (2012): Effect of deicing salts on urban soils and the health of roadside pines (Pinus tabulaeformis) in Northeast China. - Applied Mechanics and Materials 178-181: 353-356. 